\title{
Incidence of Obesity Does Not Appear to Be Increased after Treatment of Acute Lymphoblastic Leukemia in Brazilian Children: Role of Leptin, Insulin, and IGF-1
}

\author{
Carla Papadia $^{a}$ Luciana A. Naves $^{\mathrm{a}}$ Sandra S.S. Costa ${ }^{\mathrm{b}}$ Janete A.R. Vaz ${ }^{\mathrm{b}}$ \\ Lucilia Domingues $^{\text {a }}$ Luiz Augusto Casulari ${ }^{\mathrm{C}}$ \\ a Department of Endocrinology, University of Brasília, 'b Sabin Laboratory, Brasília DF, and 'Neurosurgery Unit, \\ Hospital de Base do Distrito Federal, Escola Superior em Ciências da Saúde, SES-DF, Brasilia, Brazil
}

\section{Key Words}

Leukemia $\cdot$ Obesity $\cdot$ Leptin $\cdot$ Insulin $\cdot$ IGF-1

\begin{abstract}
Background/Aims: It has been reported that children treated for acute lymphoblastic leukemia (ALL) in developed countries show an increased risk of overweight and obesity in adolescence and adulthood. However, the majority of patients who came to our observation in Brazil have low or normal body weight and only one of them was obese. Therefore, we have decided to assess some biochemical parameters possibly related to the intermediate metabolism and body composition in these patients. Methods: Two groups of subjects were studied: 27 survivors of childhood ALL (14.0 \pm 4.2 years old; post-treatment interval $8.6 \pm 3.9$ years) (ALL group) and 17 healthy subjects ( $12.8 \pm 4$ years old) (control group) selected on the basis of their kinship with the patients. Results: $14 / 27$ patients of the ALL group and 4/17 of the control group had leptin levels higher than the normal range for age and sex $(p<0.05)$. The leptin level was significantly higher in the ALL group $(15.5 \pm 1.8 \mathrm{ng} / \mathrm{ml})$ than in the control group $(10.7 \pm 2 \mathrm{ng} / \mathrm{ml})(\mathrm{p}<0.05)$. When adjusted by sex, BMI z-score, and age, the level of leptin in patients of the
\end{abstract}

ALL group was 8.5 higher than in subjects of the control group ( $p=0.006$ ). Leptin/insulin correlation in the ALL group was 0.08 and in the control group it was $+0.585(p<0.05)$. Conclusion: The data indicate the presence of alterations in the homeostatic regulatory mechanisms controlling body weight in Brazilian patients treated for ALL in childhood, still, it did not lead to obesity in the absence of favorable environmental conditions.

Copyright $\odot 2007$ S. Karger AG, Basel

\section{Introduction}

Obesity is considered a frequent complication in longterm acute lymphoblastic leukemia (ALL) survivors who show a tendency to gain body weight starting shortly after the end of the therapy [1-3]. This phenomenon might be associated with a significant earlier appearance of the so-called adiposity rebound [2]. The adiposity rebound is the period in childhood, between 5 and 7 years of age, when the body mass index (BMI) and other adiposity indices begin to increase after their nadir. An early adiposity rebound is associated with a substantially increased risk of adult obesity [2].

\section{KARGER}

Fax +4161306 1234 E-Mail karger@karger.ch www.karger.com
(C) 2007 S. Karger AG, Basel 0301-0163/07/0684-0164\$23.50/0

Accessible online at:

www.karger.com/hre
Luiz Augusto Casulari

SCN quadra 1 bloco F, Ed America Office Tower

Salas $1105 / 06$

70710-500 Brasília, DF (Brazil)

Tel./Fax +613328 0228, E-Mail lacasulari@unb.br 
In ALL survivors, a high frequency of obesity has been reported: $38 \%$ [4-7], 36\% [8], 45\% in males and $47 \%$ in females [9]. Moreover, these patients show a higher percentage of fat mass than healthy controls in spite of similar BMI [10-12].

However, there is no consensus on the mechanisms that might contribute to obesity and overweight in ALL survivors. It has been suggested that cranial radiotherapy could produce a higher risk of obesity in adulthood [3, 4, 7, 9-11, 13-19]. Sklar et al. [18] described an incidence of obesity of $38 \%$ and $40 \%$ when 24 and 18 Gy cranial radiotherapy were used, respectively, in addition to chemotherapy. On the contrary, chemotherapy alone produced obesity in only $10.5 \%$ of the treated patients. Nevertheless, no other author found any relationship between radiotherapy and obesity in ALL survivors $[1,8,20]$. Similarly, chemotherapy alone has been associated with obesity by some authors $[1,3,6,7,21]$, but not by others $[8$, 11]. In studies in which a positive correlation was found, chemotherapy, mainly by glucocorticoids, was shown to decrease fat oxidation during fasting [21] and to produce a significant increase in weight gain immediately after the beginning of the therapy [15] and after the end of it $[20,22,23]$.

It has been proposed by some authors that obesity in ALL survivors can be explained by their reduced physical activity in comparison with healthy controls [24], but no difference in energy expenditure and calories consumed could be verified between treated and control subjects [25].

Hormonal changes possibly related to obesity and overweight have been described in patients treated for ALL. ALL survivors affected by growth hormone (GH) deficit due to cranial radiotherapy have higher fat stores than healthy controls, and GH replacement improves their body composition [12]. A correlation between GH deficit and obesity or overweight has been observed by some authors $[10,11,26]$, but not by all of them $[8,9]$.

Leptin, a hormone produced by the adipose tissue, acts as an afferent signal of satiation in a feedback loop involving specific areas of the brain associated with appetite and satiety. The final effect of this loop is to regulate body fat. However, obese patients have high plasma leptin levels suggesting that they have leptin resistance [27-29]. Similarly, leptin resistance is probably present in patients treated for ALL, since leptin levels are elevated and associated with obesity $[1,10,12,16,30,31]$. Hyperinsulinemia and reduced insulin sensitivity have also been described to be associated with weight gain in ALL survivors $[12,26]$.
The aim of this study was to analyze some of the most important biochemical markers involved with obesity (leptin, insulin, and insulin-like growth factor 1 (IGF-1) blood levels) in a group of patients submitted to ALL treatment during childhood and who, unlikely those described in literature, are not obese but, otherwise, have a high frequency of low or normal body weight. We hypothesized that different life style conditions of the patients included in this study, when compared to those of more developed countries, play a critical role in preventing the obesity development.

\section{Methods}

From August 2002 to February 2003, 27 patients treated for ALL (ALL group) during childhood at the Department of Hematology and Hemotherapy of the 'Hospital de Base do Distrito Federal' were included in the study. They had an average age ( \pm SE) of $14.0 \pm 0.8$ years (range, 6 to 21 years); 15 males $(13.3 \pm 1.3$ years old) and 12 females (15.2 \pm 0.9 years old). The mean age of the patients at the time of diagnosis and treatment for ALL was $5.5 \pm 0.7$ years (range $1-14$ years). The time elapsed from the end of the treatment and the current evaluation was $8.6 \pm 0.8$ years (range 2-14 years). When included in this study, all the patients were in complete remission for at least 2 years. No patient was below the 2.5th percentile for the Brazilian children of the same age and sex [32]. No patient was submitted to bone marrow transplant. Five patients out of the initial 32 patients were excluded from the analysis because of living outside Brasilia town.

Patients had received $18 \mathrm{~Gy}(\mathrm{n}=23)$ or $24 \mathrm{~Gy}(\mathrm{n}=4)$ of total cranial irradiation in addition to chemotherapy. Central nervous system prophylaxis was performed through external conventional $10 \mathrm{MV}$ irradiation delivered by a linear accelerator. They have received only whole brain irradiation, without spine targeting. Children younger than 11 years of age were treated daily, 5 times a week, with 1.5 Gy per session; with 1.8 Gy per session, if older. ALL chemotherapy consisted of one of the following protocols: BFM-83, BFM-86, BFM-87 or GBTL-1 [33].

These patients were compared to a group of 17 healthy subjects (control group) including 11 females and 6 males with a comparable mean age of $12.8 \pm 1$ years (range $8-21$ years). No statistically significant difference in age was found between ALL and control groups. No subject was below the 2.5 th percentile for the Brazilian children of same age and sex [32]. The control group was selected among relatives of the patients (brothers, sisters, or cousins). Our objective was to avoid bias due to different socioeconomic, environmental and cultural conditions between the two groups. The control subjects were healthy and did not use any medication.

Weight and height were measured in erect position and BMI was calculated using the following formula: BMI = weight $(\mathrm{kg}) /$ height $\left(\mathrm{m}^{2}\right)$. A BMI standard deviation score $(\mathrm{z})$ was calculated for each value with the normal reference of Cole et al. [34]. Waist circumference was measured by a measuring tape at the navel level and hip circumference over trochanters. 
Table 1. Anthropometric parameters and leptin, insulin, and IGF-1 serum levels in patients treated for ALL during childhood and healthy controls (range in parentheses)

\begin{tabular}{lcc}
\hline & ALL $(\mathrm{n}=27)$ & Control $(\mathrm{n}=17)$ \\
\hline Waist, cm & $72.0 \pm 2.8^{*}(52-99)$ & $63.6 \pm 2.0(50-81)$ \\
Hip, cm & $83.6 \pm 2.7(62-102)$ & $79.1 \pm 3.0(61-105)$ \\
Waist/hip ratio & $0.85 \pm 0.02(0.75-1.18)$ & $0.81 \pm 0.01(0.72-0.93)$ \\
BMI z-score & $-0.03 \pm 1.10(-0.48$ to 0.42$)$ & $-0.49 \pm 0.57(-0.81$ to -0.17$)$ \\
Leptin, ng/ml & $15.5 \pm 1.8(2.1-28.8)^{*}$ & $10.7 \pm 2.0(1.6-27.7)$ \\
Insulin, $\mu \mathrm{U} / \mathrm{ml}$ & $6.9 \pm 1.0(2.5-31.3)$ & $7.5 \pm 1.1(2.9-15.9)$ \\
IGF-1, $\mathrm{ng} / \mathrm{ml}$ & $302.7 \pm 21.6(83.8-465)$ & $360.6 \pm 30.7(175-513.8)$ \\
\hline \multicolumn{2}{c}{$* \mathrm{p}<0.05$ ALL $\times$ control (Student t test). } \\
\hline
\end{tabular}

Blood samples were drawn to measure leptin, insulin, and IGF-1. Patients came to the laboratory between 8 and 9 a.m. after overnight fasting for blood collection. Blood samples were centrifuged at 3,000 rpm for $10 \mathrm{~min}$ and the serum was stored at $-20^{\circ} \mathrm{C}$ until assayed. Laboratory evaluations were conducted using commercial kits: insulin was assayed by a chemiluminescence assay (Wallac, São Paulo, Brazil) (normal range from 2.1 to $14.8 \mu \mathrm{U} /$ $\mathrm{ml}$ ). Leptin and IGF-1 were assayed by radioimmunometric assays (Wallac, São Paulo, Brazil) (normal range for leptin: from 2 to $17 \mathrm{ng} / \mathrm{ml}$ for females and from 1 to $11 \mathrm{ng} / \mathrm{ml}$ for males). The normal range for IGF-1 is age dependent: from 2 to 5 years between 65 and $100 \mathrm{ng} / \mathrm{ml}$; from 6 to 10 years between 95 and 400 $\mathrm{ng} / \mathrm{ml}$; from 11 to 18 years between 130 and $850 \mathrm{ng} / \mathrm{ml}$; from 19 to 30 years between 110 and $494 \mathrm{ng} / \mathrm{ml}$.

\section{Statistical Analysis}

Data were analyzed by the one-way analysis of variance (ANOVA) using the Student's t test for comparisons. For frequency analysis, the Fisher test or $\chi^{2}$ test were used. The Pearson test was used for the analysis of correlations. To assess the effect of the variable group (ALL and control) in the leptin, insulin, and IGF-1 levels, controlling variables sex, BMI z-score, and age, a multiple regression linear analysis was performed. For insulin, logarithmic transformation was used to stabilize the variance and normalize the error term. Data are presented as mean \pm SE. The level of statistical significance was fixed at $p<0.05$. Analyses were performed using the Statistical Package for Social Sciences (SPSS) version 6.0.

Ethics

The study was approved by the Research Ethics Committee of the 'Secretaria de Estado de Saúde do Distrito Federal' (Approval n.070/03). Informed consent was obtained by all the participants and/or from their parents.

\section{Results}

As shown in table 1, the ALL group had waist circumference significantly larger than that of the control group $(p<0.05)$. However, no statistically significant differences of the hip circumference, waist/hip ratio and BMI zscore were found between the two groups.
Table 2. Multiple linear regression of leptin, insulin, and IGF-1 levels controlled by sex, BMI z-score and age between patients treated for ALL during childhood and healthy controls

\begin{tabular}{lccl}
\hline Variable & $\begin{array}{l}\text { Parameter } \\
\text { estimate } \pm \text { SEM }\end{array}$ & t value & $\mathrm{p}$ \\
\hline Leptin, $\mathrm{ng} / \mathrm{ml}$ & $8.5 \pm 2.9$ & 2.9 & 0.006 \\
Insulin, $\mu \mathrm{U} / \mathrm{ml}$ & $0.08 \pm 0.17$ & 0.4 & 0.63 \\
IGF-1, ng/ml & $-25.0 \pm 39.8$ & -0.6 & 0.53 \\
\hline
\end{tabular}

With BMI adjusted for age and sex distribution in ALL group, results were as follows: 1 patient $(3.7 \%)$ had malnutrition, 5 (18.5\%) low body weight, seventeen $(63 \%)$ normal body weight; 3 (11\%) overweight and $1(3.7 \%)$ obesity. In the control group, $2(13 \%)$ subjects had low body weight and 15 (87\%) had normal body weight.

The mean leptin serum level was significantly higher in the ALL group than in the control group $(\mathrm{p}<0.05)$ (table 1). Fourteen patients (51.8\%) of the ALL group had leptin levels out of the normal upper range for age and sex, in comparison with only 4 subjects $(23.5 \%)$ in the control group $(\mathrm{p}<0.001)$. Insulin and IGF-1 levels were similar between the two groups (table 1). Insulin levels were out of the normal upper range in 1 subject of each group. IGF-1 levels were lower than the normal range for age and sex in 2 patients (7.4\%) of the ALL group and in none of the control group.

Table 2 shows multiple linear regressions of leptin, insulin, and IGF-1 levels controlled by sex, BMI z-score, and age between ALL and control groups. As we can see, patients of the ALL group had 8.5 higher leptin level than subjects of the control group $(p=0.006)$. However, no statistically significant differences were observed between the two groups in insulin $(\mathrm{p}=0.63)$ and IGF-1 $(\mathrm{p}=0.53)$ levels. 
Table 3 shows the correlations between leptin, insulin, and IGF-1 levels and the anthropometric parameters. There was no correlation between leptin and insulin levels in the ALL group, while a significant positive correlation was observed in the control group $(p<0.05)$. Significant positive correlations $(\mathrm{p}<0.05)$ were found in both groups between leptin levels and the following variables: IGF-1 level, waist and hip circumferences. However, in both groups no correlation was found for leptin levels with either waist/hip ratio or BMI z-score.

In the ALL group, no significant correlation was found between insulin levels and any parameters. In the control group, a significant positive correlation for insulin levels with IGF-1 and waist and hip circumferences. A significant negative correlation with BMI z-score was observed $(\mathrm{p}<0.05)$. Both ALL and control groups presented no correlation between insulin levels and the waist/hip ratios.

A significant positive correlation between IGF-1 level and waist and hip circumference was observed in both groups $(\mathrm{p}<0.05)$, but not between IGF-1 level and the waist/hip ratio or the BMI z-score.

\section{Discussion}

We have studied a group of patients treated for ALL in childhood who did not develop obesity during a followup period of 2-14 years after the end of therapy. Our observations are in substantial disagreement with other studies that have described a high prevalence of obesity in these patients $[3-5,7-19,23,26,31,35]$.

The body weight depends on the interaction between genetic background and environmental factors [36]. For example, it has been demonstrated that leptin receptor polymorphism may influence obesity in female survivors of ALL during childhood [19]. Female, but not male, survivors with a BMI $>25$ are more likely to be homozygous for the allele Arg223Arg of the leptin receptor gene than those with BMI <25. Moreover, among females treated with cranial irradiation (20 Gy or more) the Arg223Arg individuals have six times higher risk of a BMI $>25$ than those with the Gln223Arg allele [19].

However, environmental factors may also influence the obesity incidence. In the last 20 years, the obesity prevalence has increased worldwide due to higher food intake and reduced physical activity [36]. A classic example of the environmental influences acting on a genetic background is seen in Pima Indians. Members of the Pima community who migrated from Mexico to Arizona have higher obesity and diabetes prevalence due to
Table 3. Correlations between leptin, insulin, and IGF-1 serum levels and antropometric parameters in patients treated for ALL during childhood and healthy controls (r Pearson)

\begin{tabular}{lcc}
\hline Correlation & $\begin{array}{l}\text { ALL } \\
(\mathrm{n}=27)\end{array}$ & $\begin{array}{c}\text { Control } \\
(\mathrm{n}=17)\end{array}$ \\
\hline Leptin $\times$ insulin & 0.080 & $0.585^{*}$ \\
Leptin $\times$ IGF-1 & $0.428^{*}$ & $0.496^{*}$ \\
Leptin $\times$ waist & $0.483^{*}$ & $0.785^{*}$ \\
Leptin $\times$ hip & $0.646^{*}$ & $0.844^{*}$ \\
Leptin $\times$ waist/hip ratio & -0.051 & -0.399 \\
Leptin $\times$ BMI z-score & -0.021 & -0.178 \\
Insulin $\times$ IGF-1 & -0.108 & $0.725^{*}$ \\
Insulin $\times$ waist & 0.353 & $0.538^{*}$ \\
Insulin $\times$ hip & 0.343 & $0.677^{*}$ \\
Insulin $\times$ waist/hip ratio & 0.025 & -0.411 \\
Insulin $\times$ BMI z-score & -0.076 & $-0.543^{*}$ \\
IGF-1 $\times$ waist & $0.497^{*}$ & $0.687^{*}$ \\
IGF-1 $\times$ hip & $0.502^{*}$ & $0.758^{*}$ \\
IGF-1 $\times$ wais/hip ratio & 0.130 & -0.479 \\
IGF-1 $\times$ BMI z-score & 0.378 & -0.435 \\
\hline
\end{tabular}

${ }^{*} \mathrm{p}<0.05$ significant correlation.

a diet richer in fat and to a sedentary lifestyle in relation to those who remained in the Sierra Madre mountains of Mexico eating the traditional diet and being physically active [37]. Another example is the urbanized Australian aborigine. They are heavier and have higher prevalence of type 2 diabetes mellitus and hypertriglyceridemia than their hunter and gatherer kindreds [38]. The lifestyle of the traditional aborigines involves a low-fat diet eating game meat, fish, and vegetables and high levels of physical activity. Urbanized aborigines who were submitted to the traditional lifestyle lost weight and improved or normalized their glucose tolerance and fasting blood glucose, insulin, and triglyceride concentrations [39].

Since the patients included in this study were recruited from a public hospital that usually serves patients from the lower classes of the Brazilian community, it is possible that the absence of obesity in our ALL patients, at variance with reports from developed countries [3-5, 7-19, $23,26,31,35]$, was due to the low-fat typical Brazilian diet rich in rice, beans and vegetables. Moreover, the psychosocial attitudes (family overprotection of the sick child leading to an increased offer of high energy foods), which, as suggested by Sainsbury et al. [23], might influence weight gain in ALL survivors were probably weak in our study population.

It is noteworthy that the patients included in this study, even if not overweight, had serum leptin levels higher 
than the control subjects living in the same environmental conditions, once they have been recruited among the patient's relatives. This observation is consistent with previous reports of high serum leptin levels in patients treated for ALL during childhood $[1,10,12,16,30,31]$.

It is difficult to understand the mechanisms that underlie the hyperleptinemia in cranial-irradiated patients, but these might involve damage to the blood-brain barrier or the hypothalamus. Leptin transport from blood to the central nervous system is performed by leptin receptors localized in the endothelial cell of the blood-brain barrier and leptin receptor dysfunction might cause leptin resistance and obesity [28]. It is possible that irradiation used for prophylactic treatment of ALL may affect the blood-brain barrier receptors. Moreover, it has been suggested that hypothalamic damage could be the primary cause of obesity in children who received cranial irradiation [40]. The ventromedial hypothalamus is the site where leptin, ghrelin, neuropeptide Y-2, and insulin receptors transduce peripheral afferent signals that modulate efferent sympathetic and vagal activity, appetite, and energy balance [40].

It has been proposed that high serum leptin levels in patients treated for ALL during childhood may be either a direct consequence of radiation-induced hypothalamic damage or an indirect effect produced by a centrally induced GH deficiency [10] since the hypothalamus is more sensitive to irradiation than pituitary $[41,42]$, as shown by the lower $\mathrm{GH}$ peak response after insulin tolerance test than after the GHRH + arginine [12]. Indeed, GH treatment might reduce serum leptin level in children with GH deficiency or Prader-Willi syndrome [43], but not in survivors of childhood ALL with GH deficiency [12]. In addition, no correlation between growth hormone-binding protein and leptin in patients treated for ALL was found [1]. In the present study, leptin/IGF-1 correlation was similar in ALL and control subjects, and the patients had normal growth rates not supporting the hypotheses of a GH deficiency as the cause of hyperleptinemia.

Regulation of adiposity occurs through a classical endocrine feedback loop in which the pancreatic $\beta$-cell-derived hormone insulin and the adipocite-derived hormone leptin signal the status of body energy stores to the hypothalamus [44]. It has been suggested that excessive insulin secretion may play a role in the hypothalamic obesity after therapy for leukemia or brain tumors, because octreotide administration promoted weight loss, which correlates with reduction in insulin secretion [45]. At variance with the data of Bülow et al. [12], the present study did not find any significant difference in serum in- sulin level between ALL and control subjects. It is possible that this is due to their similar food intake of the lowfat Brazilian diet, since it is known that the amount and type of food changes insulin level and its sensitivity in target tissues [46].

In the present study, the leptin levels presented significant positive correlation with the insulin level in the control group, but not in the ALL group. This suggests an alteration in the normal leptin/insulin interaction in patients treated for ALL, even without obesity development. A direct relationship between leptin and insulin has been suggested $[27,47,48]$. For example, changes in the insulin levels were paralleled to the leptin level during weight loss, fasting, and overfeeding [48]. Leptin and insulin stimulated the insulin-receptor substrate-2 (IRS-2) PI3kinase pathway producing an anorexic effect [49].

Equally important, we found that ALL group had waist circumference significantly longer than that of the control group, while hip circumference, waist/hip ratio and $\mathrm{BMI} z$-score were similar. It has been suggested that waist circumference is a predictor of insulin resistance syndrome in children and adolescents [50]. It was also shown that increasing values of waist circumference were more consistently associated with increases in fasting and postglucose insulin levels than increasing values of waist/hip ratio [51]. The prediction of childhood obesity-related health risks is significantly improved by the inclusion of waist circumference in addition to BMI percentile [52]. In consequence, the International Diabetes Federation group recognized that there is a strong association between waist circumference, cardiovascular disease and other components of the metabolic syndrome and that $\mathrm{BMI}$ is not sufficiently sensitive to detect central obesity in different ethnic groups [53].

In conclusion, we have demonstrated that the patients treated for ALL during childhood included in our study have higher serum leptin levels than healthy kindred controls and they do not have significant leptin/insulin correlation as the control group, even if they do not develop obesity. We suggest that the low food intake of the population studied may have avoided the development of obesity.

\section{Acknowledgments}

We thank Dr. André Meireles Borba and Solange Irma Evangelista de Paula for technical assistance, and Mr. Antônio José Ribeiro Dias for statistical analysis. 


\section{References}

1 Argüelles B, Barrios V, Buño M, Madero L, Argente J: Anthropometric parameters and their relationship to serum growth hormone-binding protein and leptin levels in children with acute lymphoblastic leukaemia: a prospective study. Eur J Endocrinol 2000;143:243-250.

-2 Reilly JJ, Kelly A, Ness P, Dorosty AR, Wallace WHB, Gibson BES, Emmett PM, ALSPAC Study Team: Premature adiposity rebound in children treated for acute lymphoblastic leukemia. J Clin Endocrinol Metab 2001;86:2775-2778.

3 Odame I, Reilly JJ, Gibson BES, Donaldson MDC: Patterns of obesity in boys and girls after treatment for acute lymphoblastic leukaemia. Arch Dis Child 1994;71:147-149.

$\checkmark 4$ Zee P, Chen CH: Prevalence of obesity in children after therapy for acute lymphoblastic leukaemia. Am J Pediatr Hematol Oncol 1986;8:294-299.

5 Schell MJ, Ochs JJ, Schrock EA, Carter M: A method of predicting adult height and obesity in long term survivors of childhood acute lymphoblastic leukaemia. J Clin Oncol 1992;10:128-133.

6 Davies HA, Didcock E, Didi M, OgilvyStuart A, Wales JKH, Shalet SM: Growth, puberty and obesity after treatement for leukaemia. Acta Paediatr 1995;411(Suppl):4550.

7 Mayer EI, Reuter M, Dopfer RE, Ranke MB: Energy expenditure, energy intake and prevalence of obesity after therapy for acute lymphoblastic leukemia during childhood. Horm Res 2000;53:193-199.

-8 Birkebaek NH, Clausen N: Height and weight pattern up to 20 years after treatment for acute lymphoblastic leukaemia. Arch Dis Child 1998;79:161-164.

-9 Didi M, Didcock E, Davies HA, Ogilvy-Stuart AL, Wales JKH, Shalet SM: High incidence of obesity in young adults after treatment of acute lymphoblastic leukemia during childhood. J Pediatr 1995;127:63-67.

$\checkmark 10$ Brennan BMD, Rahim A, Blum WF, Adams JA, Eden OB, Shalet SM: Hyperleptinaemia in young adults following cranial irradiation in childhood: growth hormone deficiency or leptin insensitivity? Clin Endocrinol 1999; 50:163-169.

>11 Nysom K, Holm K, Michaelsen KF, Hertz H, Muller J, Molgaard C: Degree of fatness after treatment for acute lymphoblastic leukemia in childhood. J Clin Endocrinol Metab 1999; 84:4591-4596.

-12 Büllow B, Link K, Ahren B, Nilsson A-S, Erfurth EM: Survivors of childhood acute lymphoblastic leukaemia, with radiation-induced GH deficiency, exhibit hyperleptinaemia and impaired insulin sensitivity, unaffected by 12 months of GH treatment. Clin Endocrinol 2004;61:683-691.
13 Craig F, Leiper AD, Stanhope R, Brain C, Meller ST, Nussey SS: Sexually dimorphic and radiation dose dependent effect of cranial irradiation on body mass index. Arch Dis Child 1999;81:500-504.

14 Oeffinger KC, Mertens AC, Sklar CA, Yasui Y, Fears T, Stovall M, Vik TA, Inskip PD, Robison LL: Obesity in adult survivors of childhood acute lymphoblastic leukemia: a report from the childhood cancer survivor study. J Clin Oncol 2003;21:1359-1365.

15 Groot-Loonen JJ, Otten BJ, van't Hof MA, Lippens RJ, Stoelinga GB: Influence of treatment modalities on body weight in acute lymphoblastic leukemia. Med Pediatr Oncol 1996;27:92-97.

16 Birkebaek NH, Fisker S, Clausen N, Tuovimen V, Sindet-Pedersen S, Christiansen JS: Growth and endocrinological disorders up to 21 years after treatment for acute lymphoblastic leukemia in childhood. Med Pediatr Oncol 1998;30:351-356.

17 Warner JT, Bell W, Webb DK, Gregory JW: Relationship between cardiopulmonary response to exercise and adiposity in survivors of childhood malignancy. Arch Dis Child 1997;76:298-303.

18 Sklar CA, Mertens AC, Walter A, Mitchell D, Nesbit ME, O'Leary M, Hutchinson R, Meadows AT, Robison LL: Changes in body mass index and prevalence of overweight in survivors of childhood acute lymphoblastic leukemia: role of cranial irradiation. Med Pediatr Oncol 2000;35:91-95.

19 Ross JA, Oeffinger KC, Davies SM, Mertens AC, Langer EK, Kiffmeyer WR, Sklar CA, Stovall M, Yasui Y, Robison LL: Genetic variations in the leptin receptor gene and obesity in survivors of childhood acute lymphoblastic leukemia: a report from the Childhood Cancer Survivor Study. J Clin Oncol 2004; 22:3558-3562.

20 Van Dongen-Melman JE, Hokken-Koelega AC, Hahlen K, De Groot A, Tromp CG, Egeler RM: Obesity after successful treatment of acute lymphoblastic leukemia in childhood. Pediatr Res 1995;38:86-90.

21 Stallings VA, Vaisman N, Chan HSL, Weitzman SS, Clarke R, Pencharz PB: Energy metabolism in children with newly diagnosed acute lymphoblastic leukemia. Pediatr Res 1989;26:154-157.

22 Ahmed SF, Wallace WH, Kelnar CJ: An anthropometric study of children during intensive chemotherapy for acute lymphoblastic leukaemia. Horm Res 1997;48:178-183.

23 Sainsbury CPQ, Newcombe RG, Hughes IA: Weight gain and height velocity during prolonged first remission from acute lymphoblastic leukaemia. Arch Dis Child 1985;60 832-836.

24 Calzolari A, Baronci C, Biondi G: Evaluation of a group of leukaemic children 'off therapy' towards their inclusion in physical activities. Int J Sports Cardiol 1985;2:108-115.
25 Bond SA, Han AM, Wootton SA, Kohler JA: Energy intake and basal metabolic rate during maintenance chemotherapy. Arch Dis Child 1992;67:229-232.

-26 Talvensaari KK, Lanning M, Tapanainen P, Knip M: Long-term survivors of childhood cancer have an increased risk of manifesting the metabolic syndrome. J Clin Endocrinol Metab 1996;81:3051-3055.

27 Considine RV, Sinha MK, Helman ML, Kriauciunas A, Stephens TW, Nyce MR, Ohannesian JP, Marco CC, McKee LJ, Bauer TL, Caro JF: Serum immunoreactive leptin concentrations in normal-weight and obese humans. N Engl J Med 1996;334:292-295.

28 Casanueva FF, Dieguez C: Neuroendocrine regulation and action of leptin. Front Neuroendocrinol 1999;20:317-363.

29 Magni P, Motta M, Martini L: Leptin: a possible link between food intake, energy expenditure, and reproductive function. Regul Pept 2000;92:51-56.

30 Link K, Moell C, Garwicz S, Cavallin-Stahl E, Bjork J, Thilen U, Ahren B, Erfurth EM: Growth hormone deficiency predicts cardiovascular risk in young adults treated for acute lymphoblastic leukemia in childhood. J Clin Endocrinol Metab 2004;89:50035012.

31 Davies JH, Evans BA, Jones E, Evans WD, Jenney ME, Gregory JW: Osteopenia, excess adiposity and hyperleptinaemia during 2 years of treatment for childhood acute lymphoblastic leukaemia without cranial irradiation. Clin Endocrinol (Oxf) 2004;60: 358-365.

32 Marques RM, Marcondes E, Berquó E, Prani $\mathrm{R}$, Yunes J: Crescimento e desenvolvimento pubertário em crianças e adolescentes brasileiros. II. Altura e Peso. São Paulo, Editora Brasileira de Ciências, 1982.

33 Crist WM, Smithson WA: The leukemias; in Behrman RE, Kliegman RM, Jenson HB (eds): Nelson Textbook of Pediatrics, ed 16. Philadelphia, Saunders, 2000, pp 16941698.

34 Cole TJ, Bellizzi MC, Flegal KM, Dietz WH: Establishing a standard definition for child overweight and obesity worldwide: international survey. BMJ 2000;320:1240-1243.

35 Reilly JJ, Ventham JC, Newell J, Aitchison T, Wallace WH, Gibson BE: Risk factors for excess weight gain in children treated for acute lymphoblastic leukemia. Int J Obs Relat Metab Disord 2000;24:1537-1541.

36 Bouchard C, Perusse L: Genetics of obesity. Annu Rev Nutr 1993;3:337-354.

37 Pratley RE: Gene-environment interactions in the pathogenesis of type 2 diabetes mellitus: lessons learned from the Pima Indians. Proc Nutr Soc 1998;57:175-181. 
-38 O'Dea K, White N, Sinclair A: An investigation of nutrition-related risk factors in an isolated Aboriginal community in northern Australia: advantages of a traditionally-orientated life style. Med J Aust 1988;148:177180.

-39 O’Dea K: Marked improvement in carbohydrate and lipid metabolism in diabetic Australian aborigines after temporary reversion to traditional lifestyle. Diabetes 1983;33: 596-603.

40 Lustig RH, Post SR, Srivannaboon K, Rose SR, Danish RK, Burghen GA, Xiong X, Wu $S$, Merchant TE: Risk factors for the development of obesity in children surviving brain tumors. J Clin Endocrinol Metab 2003;88: 611-616.

-41 Constine LS, Woolf PD, Cann D, Mick G, McCormick K, Raubertas RF, Rubin P: Hypothalamic-pituitary dysfunction after radiation for brain tumors. N Engl J Med 1993; 328:87-94.

-42 Motta LACR, Martinelli C, Motta LDC, Abrahão AL, Farage Filho M, Gagliardi ART: Efeitos tardios na função hipotálamohipófise após tratamento de tumores parasselares. Arq Neuro-Psiquiatr 1991;49:299306.
43 Elimam A, Lindgren AC, Norgren S, Kamel A, Skwirut C, Bang P, Marcus C: Growth hormone treatment downregulates serum leptin levels in children independent of changes in body mass index. Hormone Res 1999;52:66-72.

44 Niswender KD, Baskin DG, Schwartz MW: Insulin and its evolving partnership with leptin in the hypothalamic control of energy homeostasis. Trends Endocrinol Metab 2004;15:362-369.

45 Lustig RH, Rose SR, Burghen GA, Velasquez-Myeyer P, Broome DC, Smith K, Li H, Hudson MM, Heideman RL, Kun LE: Hypothalamic obesity caused by cranial insult in children: altered glucose and insulin dynamics and reversal by somatostatin agonist. J Pediatr 1999;135:142-144.

46 Kaiyala KJ, Prigeon RL, Kahn SE, Woods SC, Schwartz MW: Obesity induced by a high-fat diet is associated with reduced brain insulin transport in dogs. Diabetes 2000;49:15251533.

47 Carantoni M, Abbasi F, Azhar S, Chen Y-D, Klebanov M, Wang P-W, Wamerdam F, Reaven GM: Plasma leptin concentrations do not appear to decrease insulin-mediated glucose disposal or glucose-stimulated insulin secretion in women with normal glucose tolerance. Diabetes 1998;47:244-247.
48 Kolaczynski JW, Nyce MR, Considine RV, Boden G, Nolan JJ, Henry R, Mudaliar SR, Olefsky J, Caro JF: Acute and chronic effects of insulin on leptin production in humans. Diabetes 1996;45:699-701.

49 Bates SH, Meyers MG: The role of leptin receptor signaling in feeding and neuroendocrine function. Trends Endocrinol Metab 2003;14:447-452.

50 Hirschler V, Aranda C, Calcagno Mde L, Maccalini G, Jadzinsky M: Can waist circumference identify children with the metabolic syndrome? Arch Pediatr Adolesc Med 2005;159:740-744.

51 Pouliot MC, Despres JP, Lemieux S, Moorjani S, Bouchard C, Tremblay A, Nadeau A, Lupien PJ: Waist circumference and abdominal sagittal diameter: best simple anthropometric indexes of abdominal visceral adipose tissue accumulation and related cardiovascular risk in men and women. Am J Cardiol 1994;73:460-468.

52 Lee S, Bacha F, Arslanian SA: Waist circumference, blood pressure, and lipid components of the metabolic syndrome. J Pediatr 2006;149:809-816.

53 Zimmet P, Magliano D, Matsuzawa Y, Alberti G, Shaw J: The metabolic syndrome: a global public health problem and a new definition. J Atheroscler Thromb 2005;12:295300 . 